\title{
Teachers' attitude regarding the use of ICT. A factor reliability and validity study
}

\author{
J. Pablo Hernández-Ramos*, Fernando Martínez-Abad, Francisco J. García Peñalvo, \\ M. Esperanza Herrera García, M. José Rodríguez-Conde \\ Instituto Universitario de Ciencias de la Educación, Universidad de Salamanca, Salamanca, Spain
}

\section{A R T I C L E I N F O}

Article history:

Available online 30 May 2013

\section{Keywords:}

Higher education

Information and Communication

Technologies

Psychometric analysis

Education technology

\begin{abstract}
A B S T R A C T
Current research examines the need for design and validation of a unifactorial scale to measure attitudes of university teachers with regard to ICT. The main goal of this study is to achieve a simple scale, composed of a single factor contributing a clearly reliable measure with acceptable content and factorial validity. A case study is presented, which has been developed with the teaching staff of the University of Salamanca (Spain). In this case study, an expert content validation was done at a first stage. After that, an attitude scale regarding the usage of ICT in teaching was applied with a representative sample of teachers $(N=2329 ; n=161)$. An individual analysis of the items was made with the obtained results and then a Cronbach's alpha based reliability test was carried out to show the internal consistency of the survey. Finally, an exploratory and confirmatory factor analysis was applied to prove its structural soundness and unifactoriality. The main conclusion of this paper is to offer to the scientific community a tool with adequate psychometric properties that gives added pedagogical value to the introduction of ICT in higher education teaching.
\end{abstract}

() 2013 Elsevier Ltd. All rights reserved.

\section{Introduction}

In recent years, different national and international organisations have carried out various programmes in a search for innovation and teaching improvement; for example the Bologna Process on an international level, or, on a national level, the Spanish 2.0 School Project (Muñoz, Nieto, Mendez, \& Morillejo, 2011; Saarinen, 2005).

Information and Communication Technologies (ICTs) have a recognised potential for learning support, social construction of knowledge and development of autonomous learning skills and competences (Area Moreira, 2010a; García-Peñalvo \& García Carrasco, 2002; García-Valcarcel \& Tejedor Tejedor, 2011; Gros, 2006; Verhoeven, Heerwegh, \& De Wit, 2010). For this reason, ICT have always been directly or indirectly present in all government measures taken in education.

When referring to ICT, we include in the same concept any type of technology used to create, store, exchange and process information in all its forms, such as data, voice conversations, fixed or moving images, multimedia presentations, and even

\footnotetext{
* Corresponding author. Tel.: +34 661975405.

E-mail addresses: juanpablo@usal.es (J.P. Hernández-Ramos), fma@usal.es (F. Martínez-Abad), fgarcia@usal.es (F.J. García Peñalvo), espe@usal.es (M. Esperanza Herrera García), mjrconde@usal.es (M.J. Rodríguez-Conde).
}

transmission media which have not yet been invented (Tello Díaz \& Aguaded Gómez, 2009).

We are currently facing a social reality in which, due to technological progress, the world is interconnected and everything can be located, exhibited, exchanged, transferred, received, bought, or sold independently of where we are (De Pablos, 2010); that is why higher education institutions must adapt to these changes, in order to face the new education demands of the information society. Universities, and especially university teachers, have a responsibility to contribute, by means of innovative teaching practise, to the education of individuals and to provide them with the competences they need to be able to join and participate without difficulty in the reality they will experience (González Mariño, 2008).

Based on this, in accordance with UNESCO recommendations resulting from the 2009 World Conference on Higher Education, and in order to provide solid competences for the world of today and tomorrow, and to contribute to citizenship education on ethical principles and who are committed to constructing peace and defending human rights and democratic values, we can confirm that the transformation of higher education is a reality in most countries (Tedesco, 2007).

ICT have become the transversal axis of all training actions in which they almost always have three functions: they are an instrument in learning processes, a tool for information processing and implicit learning content (Majó i Cruzate \& Marqués, 2002). 
However, follow-up and evaluation studies carried out in recent years show that, despite the fact that the majority of developed countries have made significant efforts to incorporate ICT in their education systems, the results are not what they had hoped for (Area Moreira, 2008; Pifarré, Sanuy, Vendrell, \& Gòdia, 2009; Sigalés, Mominó, Meneses, \& Badia, 2009; Stromquist, 2009).

Given this situation, it is reasonable that a number of doubts have arisen as to whether these measures were more bureaucratic in nature rather than aimed at innovation in education. There exists a possibility, therefore, that teachers may be using ICT for reasons that have nothing to do with education.

Incorporating technologies into teaching is conditioned by what teachers think and by what expectations they have regarding the use of these resources (García-Peñalvo \& García-Carrasco, 2005). Their attitude is an essential factor for the productive inclusion of ICT in training contexts (Sáez López, 2010). So, we consider attitudes towards ICT integration to be an essential factor for inclusion of the latter in university methodologies.

By attitude, we mean a predisposition to act in a particular way on the basis of incidence of cognitive, affective and behavioural components, in such a way that each element is predisposed to influence the other two (Albarracin, Johnson, \& Zanna, 2005; Erwin, 2001; Jariot García \& Montané Capdevila, 2009).

In this field in recent years there have been many studies related to the measuring of teacher attitudes towards integration of ICT in their everyday teaching activities (Cavas, Cavas, Karaoglan, \& Kisla, 2009; Richter, Naumann, \& Groeben, 2000; Teo \& Noyes, 2011). Thus, if we focus on the university environment, the main research lines show that there is real ICT integration in education, but that it is only weakly coupled to the teaching-learning processes and methodologies (Baelo \& Cantón, 2010; Pifarré et al., 2009).

To guarantee the reliability and validity of these implicit measures of attitudes (Fazio \& Olson, 2003), a great deal of research is being carried out, both in Spain and in other countries, to study the psychometric properties of the measuring tools designed for this purpose (Cavas et al., 2009; Lan, 2012; Leng, 2011; Richter et al., 2000; Tejedor, García-Valcarcel, \& Prada, 2009). Generally speaking, the reliability analyses carried out in the reports mentioned above show scales with good internal consistency indices. However, with regard to analysis of scale factorial validity, some of the studies only consider theoretical factors based on an intensive analysis of the state of the art (Leng, 2011). On the other hand, some studies involving an empirical analysis of the survey factorial validity, extract exploratory factor analysis factors without corroborating these with the confirmatory factor analysis (Cavas et al., 2009). Finally, other contributions applying confirmatory analysis propose multifactorial models obtaining goodness of fit values that are not very acceptable in some indices (Lan, 2012; Richter et al., 2000).

Therefore, based on the context described here, this paper examines the need for design and validation of a unifactorial scale to measure attitudes of university teachers with regard to ICT. The aim of the study, then, is to obtain a simple scale, composed of a single factor contributing a clearly reliable measure with acceptable content and factorial validity. Taking as a reference the pilot study developed with the teaching staff of the University of Salamanca, it is intended to generalise that scale to the whole of the faculty of the Spanish universities.

Next, we shall consider a non-experimental methodology where, based on a representative sample of the population, we shall test the resulting tool's psychometric properties after an expert validation process. After describing methodological aspects, we shall go onto present the results obtained in the reliability and factorial validity tests. Finally, these results will be discussed and evaluated.

\section{Methodology}

The research methodology is designed directly from the aim of the study. It is carried out by means of a controlled, empirical and objective systematic process and its ultimate aim is to contribute acceptable explanations for the educational phenomena being studied. In this regard, the research adapts to current methodological proposals in research in education (Green, Calimy, \& Elmore, 2006).

\subsection{Design}

The starting point for this study is a correlational descriptivetype research design based on survey studies (Kerlinger \& Lee, 2002). In this case, the methodologies are ex post-facto, because no treatment is applied to what is being studied and the relations between variables, observed in their natural context, are simply analysed. The choice of this particular methodology is a direct consequence of the general research aim; it is not a question of investigating intentional changes but one of determining or explaining a situation which is unknown to us at the outset. It is hypothesised that it is possible to obtain a single factor scale for attitudes of teachers towards ICT.

\subsection{Tool}

Based on earlier theoretical studies (Margaryan, Littlejohn, \& Vojt, 2011; Sevindik, 2011; Shih, Chu, Hwang, \& Kinshuk, 2011), a list of possible propositions to be introduced on our scale was drawn up; the scale was based on a Likert format (Likert, 1974; Morales Vallejo, Urosa, \& Blanco, 2003) with five answer options: Completely disagree (1), Disagree (2) Neither agree nor disagree (3), Agree (4) Completely agree (5). The number of possible questions is 23. All questions are designed in an affirmative way to facilitate their understanding.

It has been shown that surveys based on scales are the most widely used technique for gathering data to measure (Hernández Pina, 2009). This is because it is the most studied, reasoned and contrasted method (Morales Vallejo, 2000; Rodríguez Conde, Olmos Migueláñez, \& Martínez Abad, 2012; Tejedor et al., 2009).

Empirical evidence contributes solid support to the predictive value of self-reporting in the field of Social Sciences (Lent, 1994; Robbins et al., 2004; Rottinghaus, Larson, \& Borgen, 2003; Valentine, Dubois, \& Cooper, 2004). On the other hand, we must not forget that we are dealing with an evaluation scale of self-perceived attitudes towards the inclusion of ICTs in university teaching methodologies.

Despite the validity and consistency of the self-perception measures has been corroborated in many studies (Bandura \& Locke, 2003; Eastman \& Marzillier, 1984; Vancouver, 2005), it is proposed an implicit measure of attitudes scale (Fazio \& Olson, 2003), which presents its own peculiarities. Several authors (Gardner, 1975; Schibeci, 1988) agree on pointing out that the lack of accuracy of the definition of the measured attitudinal object causes an important methodological lack in the researches based on the attitude evaluation. In that way, some evidences indicate that the design of unifactorial scales is more suitable (Manassero Mas \& Vázquez Alonso, 2001).

\subsubsection{Content validation}

Before applying the survey to the sample, it was decided to carry out a content validation process for which two experts were selected from each of the five knowledge fields in the University of Salamanca: Arts and Humanities, Sciences, Health Sciences, Social Sciences and Engineering and Architecture. 
Table 1

Original scale for teachers' attitude toward use of ICT (Hernández-Ramos, Martínez-Abad, García-Peñalvo, García-Herrera, \& Rodríguez-Conde, 2012). University teacher attitude scale towards the use of ICT

1. ICT in university teaching implies the development of student competences

2. The performance of my classes is higher due to the use of ICT

3. New methodological possibilities arise in my classes due to the incorporation of ICT

4. Due to the incorporation of ICT in my teaching, my students are more motivated to work at my subject

5. Using ICT for the administration tasks involved in my subject (class lists, evaluation, etc.) has been a significant improvement

6. ICT result in a higher education with a greater degree of interdisciplinarity

7. Using technology in my classes improves student evaluation

8. ICT facilitate university teacher research

9. ICT improve and facilitate teacher-student communication

10. ICT save the teacher repeating work

11. Education should be mainly based on student learning needs

12. The incorporation of ICT may create anxiety

13. The use of ICT in the classroom may distract us from the main learning objectives

14. In university education teachers should provide students with skills for lifelong personal and professional development

15. ICT may become a distraction when teachers are preparing classes, and result in them focussing more on the means than the final aim

16. The use of technology in the classroom facilitates teaching for university teachers

17. University teachers are trained for correct incorporation of ICT

18. Use of ICT in teaching implies professional ongoing training and actualisation for teachers

19. Students evaluate my teaching more positively if I use ICT

20. I consider myself capable of correctly incorporating ICT in my teaching

21. University teachers have training opportunities for the integration of ICT in their daily teaching

22. Teachers should know how to find information about their subject on the Internet

23. The possibilities offered by ICT compensates for the large amount of time spent in training

$\begin{array}{lllll}1 & 2 & 3 & 4 & 5 \\ 1 & 2 & 3 & 4 & 5 \\ 1 & 2 & 3 & 4 & 5 \\ 1 & 2 & 3 & 4 & 5 \\ 1 & 2 & 3 & 4 & 5 \\ 1 & 2 & 3 & 4 & 5 \\ 1 & 2 & 3 & 4 & 5 \\ 1 & 2 & 3 & 4 & 5 \\ 1 & 2 & 3 & 4 & 5 \\ 1 & 2 & 3 & 4 & 5 \\ 1 & 2 & 3 & 4 & 5 \\ 1 & 2 & 3 & 4 & 5 \\ 1 & 2 & 3 & 4 & 5 \\ 1 & 2 & 3 & 4 & 5 \\ 1 & 2 & 3 & 4 & 5 \\ 1 & 2 & 3 & 4 & 5 \\ 1 & 2 & 3 & 4 & 5 \\ 1 & 2 & 3 & 4 & 5 \\ 1 & 2 & 3 & 4 & 5 \\ 1 & 2 & 3 & 4 & 5 \\ 1 & 2 & 3 & 4 & 5 \\ 1 & 2 & 3 & 4 & 5 \\ 1 & 2 & 3 & 4 & 5\end{array}$

The ten experts were asked to complete an online questionnaire using Google Docs, and to evaluate each of the questions proposed by awarding them a score of 1-5 for validity, clarity and relevance. They were also asked to indicate any formulation error and to make any improvements they considered necessary. The questionnaire contains the items shown in Table 1.

The global evaluations received for validity (3.9), clarity (4.2) and relevance (4) were considered adequate to continue with the process; however, based on the comments for improvement which were made, the following changes were introduced:

Items 11 and 14 were eliminated because several evaluators considered that they were student centred and did not make any contribution to a teacher attitude scale.

- Item 17 was eliminated because it was considered by three evaluators to be too ambiguous and not very clear.

- Item 20 was eliminated because, although theoretical study indicated that the item addresses a significant theme, evaluators considered it was too generic and represented all the others.

- Different specifying appositions were introduced in three items to make them clearer.

- Spelling and formulation revision was carried out in 11 items.

- So, after content validation, 14 items were rewritten because they were considered by the experts to be confusing. Other four items were eliminated for several reasons expressed above.

\subsection{Population and sample}

First of all, sample size for finite population was calculated (Arnal, del Rincón, \& Latorre, 1992; Yates, 1949), based on a population size of 2395, which includes all teachers in all departments of the University of Salamanca.

To calculate the minimum sample size, the maximum level of population variability was considered, as was a trust level of $93 \%$ $(Z=1.81)$; a sample error of $7 \%$ was established. Therefore, the minimum sample size obtained was 156 subjects. After online application of the survey, the final sample was 161 teachers.

In order to test the representativeness of the sample with regard to knowledge field, a goodness of fit test based on Pearson's chi-squared test was carried out. The results obtained guarantee that the sample chosen is distributed by population and field of knowledge: $\chi^{2}=0.8432<9.4877$ (d.f. $=4 ; \alpha=0.05$ ).

\subsection{Data analysis}

The applied target statistical analyses analyse the psychometric properties of the tool presented. Therefore, a validity and reliability analysis is included.

First of all, in order to evaluate the contribution of each item to the scale total, item-total correlation indices were analysed. For reliability analysis, the Cronbach alpha coefficient was calculated, to check scale internal consistency.

With regard to factor validity, prior conditions for factor analysis were checked (García Jiménez, Gil Flores, \& Rodríguez Gómez, 2000): Barlett test; KMO index; analysis of the main anti-image correlation matrix diagonal), the most suitable extraction method technique was applied; firstly, exploratory factor analysis using the principal component method, and secondly confirmatory factor analysis with maximum likelihood estimation (MLE). All the analyses are carried out using IBM SPSS Statistics 19 and IBM SPSS Amos 19 statistics software.

\section{Results}

The results allow performing an analysis of the psychometric properties (reliability and validity) of an evaluation scale of university teacher attitudes towards the use of ICT in teaching.

The presentation of results is divided into two clearly different parts:

- Reliability analysis: reliability is an indicator of internal consistency. Therefore, Cronbach's alpha is applied. This statistic evaluates the degree of harmonisation between the items of the scale.

- Construct or factor validity analysis: first of all exploratory factor analysis was carried out, followed by confirmatory analysis; goodness of fit indices were also analysed. Exploratory Factor Analysis is a multivariant statistical technique used mainly to specify the underlying structure in a data matrix. It analyses the inter-relational structure by using this information to calculate a series of latent dimensions, called factors, explaining these inter-relations. However, exploratory factor analysis may not be 
enough to guarantee the validity of a scale (Batista-Foguet \& Coenders, 2004). Confirmatory factor analysis, on the other hand, corrects a large number of deficiencies of the exploratory perspective and leads to greater specification of the contrasted hypotheses: as a prior hypothesis it fixes both the number of factors and their relations, using hypothesis contrasts for corroboration (Long, 1986). For this reason, it is always recommendable to apply confirmatory analysis to contrast the results obtained in the exploratory version (Kline, 2005).

\subsection{Reliability}

The fact that good reliability indices were obtained indicates that the measuring tool is precise and that it shows results, which are consistent in the different applications. The reliability test calculated is Cronbach's alpha coefficient, which gives $\alpha=0.727$; as it is higher than 0.7 it can be considered valid (Morales Vallejo et al., 2003).

However, in Table 2 we can see how Items 10, 12, 13, 15 and 22 have a very low discrimination index $(<0.3)$. As these items have a very low correlation with the rest of the elements on the scale, we have considered the possibility of eliminating them.

After analysing the theoretical contribution of all the items, it was decided to maintain Item 10 because this was considered to be an important advantage of incorporating ICT to university teaching. On the other hand, Items 12, 13, 15, and 22 were considered not to be very objective and to repeat questions that had already been asked elsewhere. It was finally decided that they should be eliminated to achieve greater global reliability.

After individual analysis of items prior to the reliability test of the tool as a whole, we obtained a scale of 15 elements, which, after recalculating the Cronbach alpha coefficient, gave a value of $\alpha=0.862$. This value indicates high internal consistency (DeVellis, 2003). In addition, all the elements on the final scale reach a discrimination index of more than 0.4 , which means that the correlation of all the items with the scale as a whole is average or above average (Morales Vallejo, 2000).

\subsection{Construct validity}

With regard to contrast of necessary conditions for factor analysis (García Jiménez et al., 2000), the following results were obtained:

Table 2

Total-element statistics.

\begin{tabular}{|c|c|c|c|c|}
\hline & \multicolumn{4}{|c|}{ Values without items } \\
\hline & Average & Variance & Correlation item-total & $\alpha$ \\
\hline Item 01 & 64.60 & 63.709 & 0.505 & 0.736 \\
\hline Item 02 & 65.16 & 61.112 & 0.540 & 0.730 \\
\hline Item 03 & 64.70 & 61.769 & 0.557 & 0.730 \\
\hline Item 04 & 65.11 & 61.645 & 0.543 & 0.731 \\
\hline Item 05 & 64.59 & 61.851 & 0.528 & 0.732 \\
\hline Item 06 & 65.34 & 63.011 & 0.408 & 0.741 \\
\hline Item 07 & 65.13 & 61.229 & 0.570 & 0.728 \\
\hline Item 08 & 64.36 & 64.155 & 0.400 & 0.742 \\
\hline Item 09 & 64.43 & 64.791 & 0.405 & 0.742 \\
\hline Item 10 & 65.69 & 63.825 & 0.294 & 0.751 \\
\hline Item 12 & 65.92 & 72.564 & -0.135 & 0.788 \\
\hline Item 13 & 65.74 & 70.715 & -0.046 & 0.779 \\
\hline Item 15 & 65.77 & 72.876 & -0.150 & 0.792 \\
\hline Item 16 & 64.46 & 63.275 & 0.587 & 0.732 \\
\hline Item 18 & 64.28 & 66.037 & 0.386 & 0.745 \\
\hline Item 19 & 65.13 & 63.558 & 0.429 & 0.740 \\
\hline Item 21 & 65.11 & 64.602 & 0.334 & 0.747 \\
\hline Item 22 & 66.08 & 67.627 & 0.176 & 0.758 \\
\hline Item 23 & 65.20 & 62.934 & 0.458 & 0.737 \\
\hline
\end{tabular}

- Barlett's test of sphericity for homogeneity of variance. $\chi^{2}=721.534 ; p<0.001 \quad$ (g.l. $=105 ; \alpha=0.05$ ). Variance was homogeneous.

- KMO index of sample suitability. $\mathrm{KMO}=0.883$. This value indicates a good correlation (Kaiser, 1974) of the variables included in the analysis.

- Main diagonal values of the anti-image correlation matrix are all greater than 0.8 . Therefore, all variables show good indices of sample suitability.

Having guaranteed homocedasticity, good correlation between variables and sample suitability, we can now go ahead with our analysis.

The results of exploratory factor analysis indicate a three-factor structure. However, whilst the extraction component matrix (Table 3 ) points to values above 0.4 for all items in the first factor (except item 21), in the other two factors the weights contributed by the items are mostly lower. The case of the item 21 is special, because, although it contributes with a small weigh (.266) to the first factor and a big weigh (.734) to the second in the exploratory factor analysis matrix, in the following confirmatory factor analysis provides a significant weigh to the only proven factor.

Confirmatory factor analysis (Table 5) indicates acceptable fit. With regard to absolute fit of the model, the Chi Squared value is significant $(p<0.05)$, which might seem to indicate that the model has an inadequate fit. However, given the sensitivity of Chi Squared to the lack of normality of some of the variables (Tejedor et al., 2009), we can resort to the freedom ratio $\chi^{2} /$ degrees, which reaches acceptable values, because it is lower than 2 (Schreiber, Nora, Stage, Barlow, \& King, 2006). On the other hand, the RMSEA (Root Mean Square Error of Approximation) points to acceptable values $(<0.08)$.

As for the incremental fit of the unifactorial model being tested, the Comparative Fit Index (CFI), which is the one normally used, because it compares several fit coefficients (Rodríguez Conde et al., $2012)$, indicates good fit $(>0.9)$. On the other hand, the Incremental Fit Index (IFI), which is more consistent than the CFI, because it takes freedom degrees into account in its calculations (Schmidt, Barreyro, \& Maglio, 2010), also indicates good fit (>0.9). Finally, the Tucker-Lewis Index (TLI), which compares fit by freedom degree of the model proposed and the null model, continues to indicate positive goodness of fit.

On the other hand, with regard to the weight each item contributes to the common factor (Fig. 1), we find adequate values for most of the items. Exceptionally, in Item 21, we find a value lower

Table 3

Factor analysis component matrix.

\begin{tabular}{llrr}
\hline & \multicolumn{2}{l}{ Component } & \multicolumn{1}{l}{3} \\
\cline { 2 - 4 } & 1 & \multicolumn{1}{l}{2} & -.284 \\
\hline Item 01 & .641 & -.351 & -.276 \\
Item 02 & .717 & .179 & -.269 \\
Item 03 & .741 & -.125 & -.211 \\
Item 04 & .691 & .152 & .418 \\
Item 05 & .611 & -.149 & -.014 \\
Item 06 & .600 & .153 & -.004 \\
Item 07 & .700 & .158 & .517 \\
Item 08 & .465 & -.408 & .280 \\
Item 09 & .500 & -.235 & .361 \\
Item 10 & .445 & .086 & .055 \\
Item 16 & .724 & .067 & -.158 \\
Item 18 & .487 & -.289 & -.116 \\
Item 19 & .521 & -.019 & .307 \\
Item 21 & .266 & .734 & -.072 \\
Item 23 & .596 & .250 & \\
\hline
\end{tabular}

Extraction by principal components. 


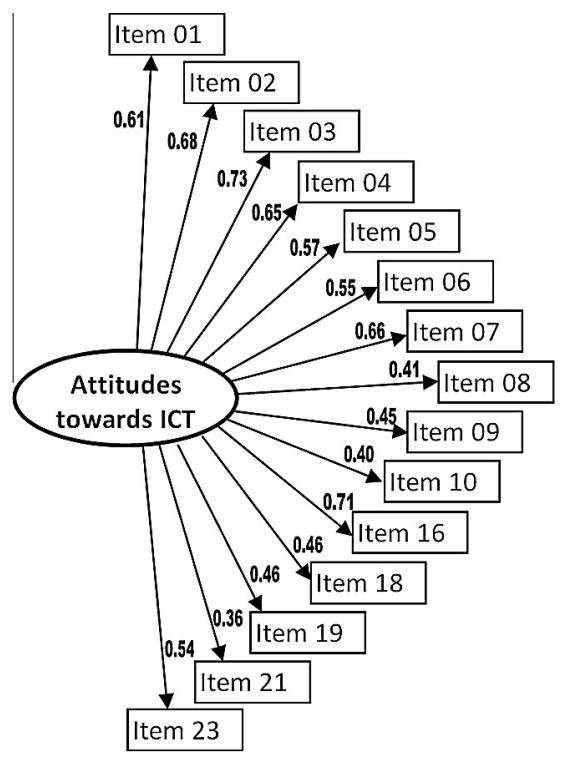

Fig. 1. Confirmatory factor analysis standarised solution.

than 0.4 ; however, if we analyse the statistical significance of the weight of this item over the factor, we obtain a significant value $(z=4.096 ; p<0.05)$.

If we carry out a short analysis of the items that contribute greater weight to the "attitudes towards ICT integration construct", we find, first of all, item 3 . This item, with the greatest factorial weight, besides making generic reference to the methodological possibilities provided by ICT, is the only one on the scale which refers explicitly to innovation processes which come about through the incorporation of ICT in teaching. The results obtained, therefore, were to be expected. Another item which registered a weight higher than 0.7 is number 16 , "the use of technology in the classroom makes university teaching easier". In this case, we are dealing again with a generic item.

With regard to items with a lesser weight, we can observe three which are below 0.45 : number 21, "University teachers have training possibilities at their disposal to enable them to incorporate ICT in their teaching"; number 10, "ICT free the teacher from carrying out repetitive work"; and number 8 , "ICT make university teacher research easier". In all three cases the items refer to a specific aspect of ICT integration. As we can see from the results, the most specific elements related to ICT integration are less important in the "attitudes towards ICT" construct than their generic aspects.

\section{Discussion}

Governments of developed countries are investing in ICT integration in their schools in order to improve the education quality of their teaching systems (OECD, 2004, 2005; Tomte \& Hatlevik, 2011), but the results obtained are not what they were hoping for. This means that many projects are being cancelled or modified. Although it has been shown in previous studies that, adequately used, ICT foster learning (García-Valcarcel \& Tejedor Tejedor, 2011; González, Rodríguez Conde, Olmos, Borham, \& García, 2013; Stromquist, 2009) there is scientific evidence to show that TIC are not being integrated into teaching and learning processes adequately (Baelo \& Cantón, 2010; Pifarré et al., 2009).

This study focuses on the attitudinal aspect of university teacher digital competence. Although in many cases this competence component is considered the least significant, we must not forget that "attitude has great impacts on improving competences"
(Wen \& Shih, 2008, p. 796), and that these positive attitudes in teachers and students result in effective integration of all types of basic competences in training processes used in the classroom (Cabero Almenara \& Alonso García, 2007; Tejedor Tejedor \& García-Valcarcel, 2006).

Based on the Theory of Reasoned Action (Ajzen \& Fishbein, 1980), the beliefs of the teachers towards the ICT as didactic tools have an influence in the attitude towards them. The own use of ICT will be based on the individual attitudes towards them. In this way, it cannot be left behind the attitude component while incorporating ICT in teaching (García-Valcárcel, 2009). When teachers have a positive attitude towards projects related to the ICT teaching integration, these projects have a higher probability of success (Anderson, 2002). For that reason, the first measure to be taken in order to integrate ICT in the teaching methodologies is to promote within the faculty an appropriate attitude towards the educational innovation and the use of ICT as tools to improve their teaching methods (Area Moreira, 2010a; García-Valcárcel, 2009).

Taking as a reference the Theory of Reasoned Action, Davis (1993) propose the Technology Acceptance Model, which explains the current use of user technologies based on their attitudes towards the own use of technologies. The attitude towards technologies is formed depending on the perceived usefulness and the perceived ease of use. The items with the highest weigh in the studied scale are just the related to the perceived usefulness to innovate (item 3 ) and the perceived ease of use for teaching work (item 16). In this way, the present scale verifies that the attitudes of university faculty towards the use of ICT are principally explained by the perceived usefulness and ease of use (Davis, 1989, 1993; Davis, Bagozzi, \& Warshaw, 1989; Sorebo, Halvari, Gulli, \& Kristiansen, 2009). The greater perception of usefulness and ease of use, the higher punctuation obtained in an attitude scale towards the use of ICT.

Despite the fact that scientific evidence proves the soundness of self-perception methods by means of self-reporting tools (Bandura \& Locke, 2003; Vancouver, 2005), we must not forget the limitations involved in this type of ex post-facto measures when it comes to establishing sound and generalisable conclusions.

Nevertheless, the study presented here shows a survey to evaluate self-perceived attitudes of university teachers towards ICT, in which the psychometric properties of the scale drawn up are adequate, both with regard to reliability and to validity.

With regard to scale reliability, after selecting the most consistent items both on a theoretical and empirical level, by means of item-total correlation index analysis, a highly acceptable Cronbach $\alpha$ value was obtained $(>0.85)$. This result shows that the instrument has high internal consistency. It is generally considered that on scales of this type a Cronbach $\alpha$ coefficient value between 0.8 and 0.9 indicates that the instrument has been properly designed. (DeVellis, 2003; Lan, 2012).

As for validity, content validity is guaranteed by the carrying out of a sound validation process by experts in the field. In the factor or construct validity test, a single factor scale with good global and incremental goodness of fit indices was obtained. Therefore, the research aims would seem to be satisfactory, because a more parsimonious scale than those already available (Lan, 2012; Richter et al., 2000; Tejedor et al., 2009) with a single factor model showing acceptable goodness of fit, has been obtained. The results achieved in this research, therefore, would seem to indicate that attitudes towards use of ICT are a measurable construct. The final scale, shown in Table 4, consists of 15 items, from the original set of 23 .

As in all studies, there are strong and weak points related to the methodological process used. In general, we can indicate as a weak point the nature of the information-gathering instrument. Self-perception scales, in this case referring to attitudes toward ICT use, 
Table 4

Final scale for teachers' attitude toward use of ICT.

\begin{tabular}{|c|c|c|c|c|c|c|}
\hline & University teacher attitude scale towards the use of ICT & & & & & \\
\hline 1. & The use of ICT in university teaching implies the development of new student competences & 1 & 2 & 3 & 4 & 5 \\
\hline 2. & More work is carried out in my classes due to the use of ICT & 1 & 2 & 3 & 4 & 5 \\
\hline 3. & $\begin{array}{l}\text { New methodological possibilities arise in my classes and I can put teaching innovations into practice more easily due to the incorporation of } \\
\text { ICT }\end{array}$ & 1 & 2 & 3 & 4 & 5 \\
\hline 4. & Due to the incorporation of ICT in my teaching, my students are more motivated to work at my subject & 1 & 2 & 3 & 4 & 5 \\
\hline 5. & Using ICT for the administration tasks involved in my subject (class lists, evaluation, etc.) has been a significant improvement & 1 & 2 & 3 & 4 & 5 \\
\hline 6. & ICT result in a higher education with a greater degree of interdisciplinarity & 1 & 2 & 3 & 4 & 5 \\
\hline 7. & Using technology in my classes improves student evaluation & 1 & 2 & 3 & 4 & 5 \\
\hline 8. & ICT facilitate university teacher research & 1 & 2 & 3 & 4 & 5 \\
\hline 9. & ICT improve and facilitate teacher-student communication & 1 & 2 & 3 & 4 & 5 \\
\hline 10. & ICT save the teacher repeating work & 1 & 2 & 3 & 4 & 5 \\
\hline 16. & The use of technology in the classroom facilitates teaching for university teachers & 1 & 2 & 3 & 4 & 5 \\
\hline 18. & Adequate use of ICT in teaching implies professional ongoing training for teachers & 1 & 2 & 3 & 4 & 5 \\
\hline 19. & Students evaluate my teaching more positively if I use ICT & 1 & 2 & 3 & 4 & 5 \\
\hline 21. & University teachers have training opportunities for the integration of ICT in their teaching & 1 & 2 & 3 & 4 & 5 \\
\hline 23. & The possibilities opened up to the teacher by certain ICT compensates for the large amount of time spent in training & 1 & 2 & 3 & 4 & 5 \\
\hline
\end{tabular}

Table 5

Confirmatory factor analysis index.

\begin{tabular}{|c|c|c|c|c|c|c|}
\hline \multicolumn{4}{|c|}{ Global fit } & \multicolumn{3}{|c|}{ Incremental fit } \\
\hline$\chi^{2}$ & $\chi^{2} / \underline{\mathrm{df}}$ & $p$ & $\underline{\text { RMSEA }}$ & CFI & $\underline{\mathrm{IFI}}$ & $\underline{\text { TLI }}$ \\
\hline 131.8 & 1.481 & 0.002 & 0.055 & 0.934 & 0.935 & 0.922 \\
\hline
\end{tabular}

Maximum likelihood estimation.

have an inherent subjective component. Therefore, in order to facilitate the objectivity of the observations, it would seem appropriate to combine the use of this scale with instruments for real evaluation of the competence measured.

Strong points would include the fact that, in order to measure attitudes towards ICT use, a scale with higher than acceptable psychometric qualities was constructed; on the one hand, reliability indices show good internal consistency, and, on the other, there is evidence of good adjustment of the unifactorial scale. Although RMSEA index value exceeds .05 , it is considered good fit to be below 07 (Steiger, 2007), and even below .06 (Hu \& Bentler, 1999). Therefore, unlike other studies showing ICT attitude scales (Cavas et al., 2009; Lan, 2012; Leng, 2011; Richter et al., 2000; Tejedor et al., 2009), this study shows a scale with a single factorial structure and good indices of global and incremental adjustment.

The research significantly contributes to the study of the attitudes towards the use of the ICT's among the university faculty, since it shows a simple scale with good psychometric properties. Moreover, it settles the theoretical bases for the design and adaptation of unifactorial scales of implicit measure of attitudes towards the use of ICT. The importance of this kind of scales in the practice is wide. This kind of scales have a great importance in the practice, since it is verified that the attitudes determine in large part the own convictions and eventually the behaviour concerning the use and integration of ICT (Ajzen et al., 1980; Davis, 1989, 1993; García-Valcárcel, 2009).

With regard to future lines of research arising from this study, we would like to consider various aspects. First of all, the present scale, given its simple nature, could form part of larger inventories applied in future studies for the global evaluation of digital competences. Secondly, this study opens the door to future research regarding design of objective instruments for evaluation of teacher attitudes towards ICT use, considering this unifactorial construct adjusted to observable reality. Finally, in the area of teacher attitude scale reliability and viability studies, this study reveals a need to develop parsimonious studies with good indices of internal consistency and scale adjustment.
In conclusion, we must point out the importance of the design of this type of scales as a step to be taken prior to the adequate integration of ICT in university teaching practice (Area Moreira, 2010b; Liu \& Szabo, 2009) since empirical research shows that positive attitudes towards ICT facilitates their integration in education (Sang, Valcke, van Braak, \& Tondeur, 2010; Teo \& Noyes, 2011).

\section{Acknowledgments}

Spanish National R+D+i Project, 2009: Evaluation of Key Competences and Secondary School Teacher Training: ICT, InfoLit and School Environment (EF-TALCO). Ref: EDU2009-08753.

\section{References}

Ajzen, I., \& Fishbein, M. (1980). Understanding attitudes and predicting social behaviour. New Jersey: Prentice-Hall.

Albarracin, D., Johnson, B. T., \& Zanna, M. P. (Eds.). (2005). The handbook of attitudes. Philadelphia: Psychology Press.

Anderson, R. (2002). Guest editorial: International studies on innovative uses of ICT in schools. Journal of Computer Assisted Learning, 18, 381-386.

Area Moreira, M. (2008). Innovación pedagógica con TIC y el desarrollo de las competencias informacionales y digitales. Investigación en la escuela, 64, 5-18.

Area Moreira, M. (2010a). Por qué formar en competencias informacionales y digitales en la educación superior? Revista de Universidad y Sociedad del Conocimiento, 7(2), 2-5.

Area Moreira, M. (2010b). El proceso de integración y uso pedagógico de las TIC en los centros educativos: Un estudio de casos. Revista de Educación, 352, 77-97.

Arnal, J., del Rincón, D., \& Latorre, A. (1992). Investigación educativa: Fundamentos y metodologías (1a. ed.). Barcelona: Labor.

Baelo, R., \& Cantón, I. (2010). Las TIC en las Universidades de Castilla y León. Comunicar, 35, 159-166.

Bandura, A., \& Locke, E. A. (2003). Negative self-efficacy and goal effects revisited. The Journal of Applied Psychology, 88(1), 87-99.

Batista-Foguet, J. M., \& Coenders, G. (2004). Análisis factorial confirmatorio. Su utilidad en la validación de cuestionarios relacionados con la salud. Medicina Clínica, 122, 21-27.

Cabero Almenara, J., \& Alonso García, C. M. (2007). Nuevas tecnologías aplicadas a La educación. Madrid: McGraw Hill.

Cavas, B., Cavas, P., Karaoglan, B., \& Kisla, T. (2009). A study on science teachers attitudes toward information and communication technologies in education. Turkish Online Journal of Educational Technology, 8(2), 20-32.

Davis, F. D. (1989). Perceived usefulness, perceived ease of use, and user acceptance of information technology. MIS Quarterly, 13(3), 319. http://dx.doi.org/10.2307/ 249008.

Davis, F. D. (1993). User acceptance of information technology: System characteristics, user perceptions and behavioral impacts. International Journal of Man-Machine Studies, 38(3), 475-487. http://dx.doi.org/10.1006/ imms.1993.1022.

Davis, F. D., Bagozzi, R. P., \& Warshaw, P. R. (1989). User acceptance of computer technology: A comparison of two theoretical models. Management Science, 35(8), 982-1003. http://dx.doi.org/10.1287/mnsc.35.8.982. 
De Pablos, J. de. (2010). Universidad y sociedad del conocimiento. Las competencias informacionales y digitales. Revista de Universidad y Sociedad de Conocimiento, $7(2), 6-16$

DeVellis, D. R. F. (2003). Scale development: theory and applications (2nd ed.). Sage Publications, Inc.

Eastman, C., \& Marzillier, J. S. (1984). Theoretical and methodological difficulties in Bandura's self-efficacy theory. Cognitive Therapy and Research, 8(3), 213-229.

Erwin, P. (2001). Attitudes and persuasion. Philadelphia: Psychology Press.

Fazio, R. H., \& Olson, M. A. (2003). Implicit measures in social cognition research: Their meaning and use. Annual Review of Psychology, 54, 297-327.

García Jiménez, E., Gil Flores, J., \& Rodríguez Gómez, G. (2000). Análisis factorial. Madrid: La Muralla.

García-Peñalvo, F. J., \& García Carrasco, J. (2002). Los espacios virtuales educativos en el ámbito de Internet: Un refuerzo a la rormación tradicional. Teoría de la Educación. Educación y Cultura en la Sociedad de la Información. 3.

García-Peñalvo, F. J., \& García-Carrasco, J. (2005). Educational hypermedia resources facilitator. Computers \& Education, 44(3), 301-325. http://dx.doi.org/10.1016/ j.compedu.2004.02.004.

García-Valcárcel, A. (2009). La Incorporación de las TIC en la docencia universitaria: recursos para la formación del profesorado. Barcelona: Davinci.

García-Valcarcel, A., \& Tejedor Tejedor, F. J. (2011). Variables TIC vinculadas a la generación de nuevos escenarios de aprendizaje en la enseñanza universitaria. Aportes de las Curvas ROC para el análisis de diferencias. Educación XXI: Revista de la Facultad de Educación, 14(2), 43-78.

Gardner, P. L. (1975). Attitudes to science: A review. Studies in Science Education, 2, $1-41$.

González, A. B., Rodríguez Conde, M. J., Olmos, S., Borham, M., \& García, F. (2013). Experimental evaluation of the impact of B-learning methodologies on engineering students in Spain. Computers in Human Behavior, 29(2), 370-377. http://dx.doi.org/10.1016/j.chb.2012.02.003.

González Mariño, J. C. (2008). TIC y la transformación de la práctica educativa en el contexto de las sociedades del conocimiento. Revista de Universidad y Sociedad del Conocimiento, 5(2).

Green, J., Calimy, G., \& Elmore, P. (2006). Complementary methods in education research. Mahwah, New Jersey: L. Erlbaum.

Gros, B. (2006). Qué debe saber el profesorado? Cuadernos de pedagogía, 363, 58-65.

Hernández Pina, F. (2009). Aprendizaje y competencia. Una nueva mirada. Revista Española de Orientación y Psicopedagogía, 20(3), 312-319.

Hernández-Ramos, J. P., Martínez-Abad, F., García-Peñalvo, F. J., García-Herrera, E., \& Rodríguez-Conde, M. J. (2012). Teacher attitude scale regarding the use of ICT. Reliability and validity study. In F. J. García-Peñalvo, L. Vicent, M. Ribó, A Climent, J. L. Sierra, \& A. Sarasa (Eds.), 2012 International symposium on computers in education (SIIE). Los Alamitos, CA, USA: Institute of Electrical and Electronics Engineers.

Hu, L., \& Bentler, P. M. (1999). Cutoff criteria for fit indexes in covariance structure analysis: Conventional criteria versus new alternatives. Structural Equation Modeling: A Multidisciplinary Journal, 6(1), 1-55.

Jariot García, M., \& Montané Capdevila, J. (2009). Actitudes y velocidad en jóvenes. Aplicación de un programa de educación vial. Relieve: Revista Electrónica de Investigación y Evaluación Educativa, 15(1).

Kaiser, H. F. (1974). An index of factorial simplicity. Psychometrika, 39(1), 31-36.

Kerlinger, F., \& Lee, H. (2002). Investigación del comportamiento, métodos de investigación en Ciencias Sociales. México: McGrawHill.

Kline, R. (2005). Principles and practice of structural equation modeling. New York: Guilford Press.

Lan, Y.-L. (2012). Development of an attitude Scale to assess K-12 teachers' attitudes toward nanotechnology. International Journal of Science Education, 34(8), 1189-1210. http://dx.doi.org/10.1080/09500693.2011.651657.

Leng, N. W. (2011). Reliability and validity of an information and communications technology attitude scale for teachers. Asia-Pacific Education Researcher, 20(1), $162-170$

Lent, R. W. (1994). Toward a unifying social cognitive theory of career and academic interest, choice, and performance. Journal of Vocational Behavior 45(1), 79-122.

Likert, R. (1974). A method of constructing an attitude scale. In G. M. Maranell (Ed.), Scaling; A sourcebook for behavioral scientists (pp. 233-243). Chicago: Aldine.

Liu, Y., \& Szabo, Z. (2009). Teachers' attitudes toward technology integration in schools: A four-year study. Teachers and Teaching, 15(1), 5-23. http://dx.doi.org 10.1080/13540600802661295.

Long, J. (1986). Confirmatory factor analysis. A preface to LISREL. Beverly Hills: Sage Publ.

Majó i Cruzate, J., \& Marqués, P. (2002). La revolución educativa en la era internet. Barcelona: CissPraxis

Manassero Mas, M. A., \& Vázquez Alonso, A. (2001). Instrumentos y métodos para la evaluación de las actitudes relacionadas con la ciencia, la tecnología y la sociedad. Enseñanza de las ciencias, 20(1), 15-27.

Margaryan, A., Littlejohn, A., \& Vojt, G. (2011). Are digital natives a myth or reality? University students' use of digital technologies. Computers \& Education, 56(2) 429-440. http://dx.doi.org/10.1016/j.compedu.2010.09.004.

Morales Vallejo, P. (2000). Medición de actitudes en psicología y educación: Construcción de escalas y problemas metodológicos. Madrid: Universidad Pontificia Comillas.

Morales Vallejo, P., Urosa, S., \& Blanco, A. (2003). Construcción de escalas de actitudes tipo likert: Una guía práctica. Madrid: La Muralla.
Muñoz, C., Nieto, B., Mendez, M., \& Morillejo, E. (2011). Evaluation of the educational activity in the European Space of Higher Education: A comparative study of quality indicators in European Universities. Revista Española de Pedagogía, 69(248), 145-163.

OECD (2004). Marcos teóricos de PISA 2003. Conocimientos y destrezas en Matemáticas, Lectura, Ciencias y Solución de problemas. Madrid: Ministerio de Educación y Ciencia.

OECD (2005). Are students ready for a technology-rich world? What PISA studies tell us (programme for international student assessment). Paris: OECD.

Pifarré, M., Sanuy, J., Vendrell, C., \& Gòdia, S. (2009). Internet en la educación secundaria: pensar, buscar y construir conocimiento en la red. Lleida: Milenio.

Richter, T., Naumann, J., \& Groeben, N. (2000). Attitudes toward the computer: Construct validation of an instrument with scales differentiated by content. Computers in Human Behavior, 16(5), 473-491. http://dx.doi.org/10.1016/ S0747-5632(00)00025-X.

Robbins, S. B., Lauver, K., Le, H., Davis, D., Langley, R., \& Carlstrom, A. (2004). Do psychosocial and study skill factors predict college outcomes? A metaanalysis. Psychological Bulletin, 130(2), 261-288.

Rodríguez Conde, M. J., Olmos Migueláñez, S., \& Martínez Abad, F. (2012) Propiedades métricas y estructura dimensional de la adaptación española de una escala de evaluación de competencia informacional autopercibida (ILHUMASS). Revista de Investigación Educativa, 30(2), 347-365.

Rottinghaus, P. J., Larson, L. M., \& Borgen, F. H. (2003). The relation of self-efficacy and interests: A meta-analysis of 60 samples. Journal of Vocational Behavior, $62(2), 221-236$

Saarinen, T. (2005). "Quality" in the Bologna process: From "competitive edge" to quality assurance techniques. European Journal of Education, 40(2), 189-204.

Sáez López, J. M. (2010). Actitudes de los docentes respecto a las TIC, a partir del desarrollo de una práctica reflexiva. Escuela abierta: revista de Investigación Educativa, 13, 37-54

Sang, G., Valcke, M., van Braak, J., \& Tondeur, J. (2010). Student teachers' thinking processes and ICT integration: Predictors of prospective teaching behaviors with educational technology. Computers \& Education, 54(1), 103-112. http:// dx.doi.org/10.1016/j.compedu.2009.07.010.

Schibeci, R. A. (1988). Attitudes to science: Un update. Studies in Science Education, $11,26-59$.

Schmidt, V., Barreyro, J. P., \& Maglio, A. L. (2010). Escala de evaluación del funcionamiento familiar FACES III: Modelo de dos o tres factores? Escritos de Psicología, 3(2), 30-36.

Schreiber, J. B., Nora, A., Stage, F. K., Barlow, E. A., \& King, J. (2006). Reporting structural equation modeling and confirmatory factor analysis results: A review. Journal of Educational Research, 99(6), 323-337.

Sevindik, T. (2011). Determining the attitudes of the preservice teachers about distance education applications. Energy Education Science and Technology Part BSocial and Educational Studies, 3(4), 527-534.

Shih, J.-L., Chu, H.-C., Hwang, G.-J., \& Kinshuk (2011). An investigation of attitudes of students and teachers about participating in a context-aware ubiquitous learning activity. British Journal of Educational Technology, 42(3), 373-394. http://dx.doi.org/10.1111/j.1467-8535.2009.01020.x.

Sigalés, C., Mominó, J. M., Meneses, J., \& Badia, A. (2009). La integración de Internet en la educación escolar española: Situación actual y perspectivas de futuro. Barcelona: Planeta.

Sorebo, O., Halvari, H., Gulli, V. F., \& Kristiansen, R. (2009). The role of selfdetermination theory in explaining teachers' motivation to continue to use elearning technology. Computers \& Education, 53(4), 1177-1187. http:// dx.doi.org/10.1016/j.compedu.2009.06.001

Steiger, J. (2007). Understanding the limitations of global fit assessment in structural equation modeling. Personality and Individual Differences, 42(5), 893-898.

Stromquist, N. P. (2009). The impact of information and communication technologies on university students: A tentative assessment. Cultura $Y$ Educacion, 21(2), 215-226.

Tedesco, J. C. (2007). Los pilares de la educación del futuro. Revista Iberoamericana de Educación, 43(5).

Tejedor, F. J., García-Valcarcel, A., \& Prada, S. (2009). Medida de actitudes del profesorado universitario hacia la integración de las TIC. Comunicar. Revista Científica Iberoamericana de Comunicación y Educación, 17(33), 115-124.

Tejedor Tejedor, F. J., \& García-Valcarcel, A. (2006). Competencias de los profesores para el uso de las TIC en la ensenanza. Análisis de sus conocimientos y actitudes. Revista Española de Pedagogía, 64(233), 21-43.

Tello Díaz, J., \& Aguaded Gómez, J. I. (2009). Desarrollo profesional docente ante los nuevos retos de las tecnologías de la información y la comunicación en los centros educativos. Pixel-Bit. Revista de Medios y Educación, 34, 31-47.

Teo, T., \& Noyes, J. (2011). An assessment of the influence of perceived enjoyment and attitude on the intention to use technology among pre-service teachers: A structural equation modeling approach. Computers \& Education, 57(2), 1645-1653. http://dx.doi.org/10.1016/j.compedu.2011.03.002.

Tomte, C., \& Hatlevik, O. (2011). Gender-differences in self-efficacy ICT related to various ICT-user profiles in Finland and Norway. How do self-efficacy, gender and ICT-user profiles relate to findings from PISA 2006. Computers $\mathcal{E}$ Education, 57(1), 1416-1424. http://dx.doi.org/10.1016/j.compedu.2010. 12.011.

UNESCO (2009). 2009 world conference on higher education: The new dynamics of higher education and research for societal change and development. Paris: UNESCO. 
Valentine, J. C., Dubois, D. L., \& Cooper, H. (2004). The relation between self-beliefs and academic achievement: A meta-analytic review. Educational Psychologist, 39(2), 111-133.

Vancouver, J. B. (2005). The depth of history and explanation as benefit and bane for psychological control theories. The Journal of Applied Psychology, 90(1), 38-52.

Verhoeven, J. C., Heerwegh, D., \& De Wit, K. (2010). Information and communication technologies in the life of university freshmen: An analysis of change.
Computers $\mathcal{E} \quad$ Education, 55(1), 53-66. http://dx.doi.org/10.1016 j.compedu.2009.12.002.

Wen, J. R., \& Shih, W. L. (2008). Exploring the information literacy competence standards for elementary and high school teachers. Computers \& Education, 50(3), 787-806.

Yates, F. (1949). Sampling methods for censuses and surveys. London: Charles Griffin. 